\title{
Inventorying Armagh: Max Lock, civil society, and the diffusion of planning ideas into Northern Ireland in the 1960s
}

\section{Andrew G. McClelland}

To cite this article: Andrew G. McClelland (2017) Inventorying Armagh: Max Lock, civil society, and the diffusion of planning ideas into Northern Ireland in the 1960s, Planning Perspectives, 32:3, 401-423, DOI: 10.1080/02665433.2016.1277953

To link to this article: https://doi.org/10.1080/02665433.2016.1277953

Published online: 10 Feb 2017.

Submit your article to this journal $\sqsubset$

Џ Article views: 443

Q View related articles ๘

View Crossmark data \lceil

Citing articles: 1 View citing articles $\square$ 


\title{
Inventorying Armagh: Max Lock, civil society, and the diffusion of planning ideas into Northern Ireland in the 1960s
}

\author{
Andrew G. McClelland (10) \\ National Institute for Regional and Spatial Analysis (NIRSA), Social Sciences Institute (MUSSI), Maynooth University, \\ Maynooth, Ireland
}

\begin{abstract}
The cathedral city of Armagh is one of the most historically and architecturally significant on the island of Ireland. This article explores the preparation of an inventory of Armagh's architectural heritage by the London architect-planner Max Lock in 1964, commissioned by the Northern Ireland Committee of the National Trust. The inventory represents one aspect of the initial response of civil society to impending change in the built environment in the mid-1960s and formed part of efforts to ensure parity with Great Britain in land-use planning legislation. The inventory facilitates a wider discussion on state-civil society relations in Northern Ireland, the values and ideas guiding change within historic settlements, and the place promotional advantage that the local council sought to derive from Armagh's history and heritage. Utilizing Ward's typology of diffusion, it is argued that Northern Ireland represents an unusual 'within-UK' example of the transference of planning ideas and practices, with its historical experience of devolution offering valuable contemporary insights into the increasingly diffuse and fragmented governance space within the UK.
\end{abstract}

\section{KEYWORDS}

Max Lock; Armagh; architectural heritage; National Trust; civil society; planning diffusion; Northern Ireland

\section{Introduction}

On becoming Prime Minister of Northern Ireland in March 1963, the Unionist Party leader Terence O'Neill pledged to 'literally transform the face of Ulster. ${ }^{1}$ In seeking to arrest the decline of traditional local industries and outflank rival political parties, O'Neill embraced regional planning as a tool of economic modernization and 'seized the opportunity' to politically champion Robert Matthew's Belfast Regional Survey and Plan 1962 (Matthew Plan) as a strategic blueprint in his reformist agenda. ${ }^{2}$ Many enthusiastically endorsed these indicators of progress, including the built environment professions, with the 1963 Royal Society of Ulster Architects Ulster Today exhibition reassuring that the 'huge visual changes beginning to take place ... need not be regarded with dread'. ${ }^{3}$ Others, such as the National Trust for England, Wales and Northern Ireland (NT), cautiously welcomed the opportunity presented by the new political dispensation to argue for 'parity' between Northern Ireland and Great Britain in a range of policy areas concerning land-use planning and conservation. The promise of 'O'Neillism' in the period 1963-1964, in short, represented both a threat to the largely unprotected built environment through an accelerated development programme, while

CONTACT Andrew G. McClelland andrew.mcclelland@nuim.ie

${ }^{1}$ Mulholland, Terence O'Neill, 29.

${ }^{2}$ Mulholland, Northern Ireland, 23.

${ }^{3}$ McKinstry, "Introduction."

(C) 2017 Informa UK Limited, trading as Taylor \& Francis Group 
simultaneously creating the political space for long-delayed legislative and institutional reforms. The political disappointments and conflict that would grip the region from the late-1960s were unforeseeable in these early stages of O'Neill's Premiership - the violent period known as the Northern Ireland 'Troubles' ran from late 1968 to 1998, and was essentially contested between Protestant/ Unionists, who wanted Northern Ireland to remain within the UK, and Catholic/Nationalists, who sought the unification of Northern Ireland with the Republic of Ireland. Nonetheless, acrimony soon manifested in the contested arena of land-use planning and many proposed reforms remained unfulfilled until the reluctant intervention of the British Government.

This paper addresses the initial response of civil society to impending change in Northern Ireland's built environment in the early to mid-1960s. The discussion is centred on the preparation, in 1964, of an inventory of architectural heritage in Armagh by the London-based architect-planner Max Lock, which was purported to be the first of its kind in Ireland. ${ }^{4}$ The inventory was commissioned by the Northern Ireland Committee of the NT to raise awareness of the value of the local built environment and provide an exemplar of inventorying practice for others to emulate, while nudging government towards incorporating a concern for conservation into emergent development plans. In addition to augmenting the biography of a well-known planning figure, a diverse set of issues that have been the subject of recent scholarly attention are explored. Firstly, insights are offered into state-civil society relations in Northern Ireland in the 1960s, including the 'responsible style' lobbying strategies of organizations, such as the NT, when seeking to elevate conservation issues onto the political agenda. ${ }^{5}$ Secondly, the discussion considers the heritage values ascribed to the built environment of Armagh and the interventions deemed appropriate in accommodating change within this historic settlement. Thirdly, the mobilization of the inventory for place promotional purposes by the local council is highlighted in the context of the local government reform and other strategic planning initiatives proposed in the mid-1960s, including the creation of a New City and decision-making over the location of a second university in Northern Ireland. Finally, the paper examines the diffusion of planning ideas and practices in this period, utilizing the 'typology of diffusion' elaborated by Ward to characterize the unusual 'within-UK' transference that Northern Ireland represents. ${ }^{6}$

The paper begins with brief biographical details of Lock before introducing Armagh and outlining the background to the Northern Ireland Committee of the NT and its developing interest in its architectural heritage. The subsequent sections consider the issues set out above, firstly illuminating the background to Lock's commissioning before addressing what its contents reveal about attitudes to conservation of the built environment. The conclusions emphasize how the historical experience of Northern Ireland as the first devolved region of the UK can offer contemporary insights concerning the trend towards the devolution of powers and greater local autonomy, including to cities and city regions. This unfolding devolutionary process is already leading to increasing divergence in the governance of places in the UK, and hence offers scope for comparative research on the diffusion of planning ideas and practices. ${ }^{7}$

\section{Max Lock, 1909-1988}

Max Lock was born in Watford in 1909 and studied architecture at the Architectural Association in London, graduating in 1931, before progressing in his studies for town planning qualifications that

\footnotetext{
${ }^{4}$ National Trust, Annual Report [1964].

${ }^{5}$ Pendlebury and Strange, "Centenary Paper," 370.

${ }^{6}$ Ward, "Re-examining the International Diffusion," 479-98.

${ }^{7}$ House of Commons Library, Comparison of the Planning Systems, 3.
} 
same decade. Although not as prolific as Thomas Sharp and Patrick Abercrombie, Lock is associated with post-war British reconstruction planning and was responsible for four plans in the period 19421952, including Bedford, the Hartlepools, and Middlesbrough. ${ }^{8}$ However, experts such as Lock increasingly undertook commissions in other countries, thereby hastening the dissemination of planning ideas and practices around the world, particularly in developing and former colonial territories. ${ }^{9}$ This included international consultancy in Africa and the Middle East under the auspices of the United Nations and agencies of the British Government, and a less successful 'vacation' to the Caribbean during the period of his guest lectureship at the Harvard Graduate School of Design in 1957-1958. ${ }^{10}$ His extensive travels throughout his career included a pre-war trip to Scandinavia, post-war reconstruction visits to the Netherlands and Poland, and a lecture tour of India, Pakistan, and Ceylon in 1951, supported by the British Council, each of which subsequently featured in reports, lectures, and frequent radio broadcasts. Such globetrotting reflected Lock's diverse interests in planning and architecture, his wide professional network, and active involvement in the Housing Centre Trust, Modern Architectural Research Group, the Town Planning Institute, and other related groups.

Lock is also well known for the promotion of sociological research methods in plan-making and for attempting to 'place people at the centre of the process'. ${ }^{11}$ To this end, he collaborated with Ruth Glass, Jacqueline Tyrwhitt, and others in the 1940s, and their work in Middlesbrough is considered particularly 'innovative and significant' for its involvement of 'ordinary people' - a notable innovation given that it was undertaken several decades before participatory practices in the UK were investigated by the Skeffington Committee. ${ }^{12}$ In spite of his varied exploits, Lock 'never received the attention that he deserved' during his lifetime, ${ }^{13}$ and 'no substantial study' of his work has been written since his death in 1988. ${ }^{14}$ Although acting head of the School of Architecture at Hull University in 1939, establishment suspicions, together with the fact that Lock, as a Quaker, was a conscientious objector during the war, prevented this position from being confirmed on a more permanent basis. ${ }^{15}$ Why his achievements were largely 'forgotten', for Motouchi and Tiratsoo, relate to a mixture of changing political fashions, the perceived incompatibility of the planning and sociological traditions that he sought to fuse, and the failure of the man himself to disseminate his ideas more widely. ${ }^{16}$ However, even less is known about his visits to Armagh in the mid-1960s, which do not even feature as a footnote in the fragmentary references to his activities elsewhere, and are largely unknown in Northern Ireland in spite of the novelty of his intervention in the local context. ${ }^{17}$ An ironic twist to Lock's appointment as a consultant in Armagh concerns his supposed Communist sympathies as one of a number of architects and planners in the UK who the security services 'kept a close eye on'. ${ }^{18}$ Prior to O'Neill's emergence as Prime Minister in 1963, the political resistance to the idea of planning in Northern Ireland was partially due to his predecessor, Lord Brookeborough, who held the position during 1943-1963, viewing it as a 'socialist menace'. ${ }^{19}$ Uncovering 'buried history'

\footnotetext{
${ }^{8}$ Larkham and Lilley, Planning the 'City of Tomorrow' and Larkham and Lilley, "Plans, Planners and City Images," 183-205.

${ }^{9}$ Uduku, "Networking and Strategic Deal-Making."

${ }^{10}$ Bununu, Ludin, and Hosni, "City Profile: Kaduna," 53-65.

${ }^{11}$ Shapely, People and Planning, vi.

${ }^{12}$ Motouchi and Tiratsoo, "Max Lock, Middlesbrough," 19.

${ }^{13}$ Ibid., 20.

${ }^{14}$ Darling, Re-forming Britain, 250.

${ }^{15}$ Motouchi and Tiratsoo, "Max Lock, Middlesbrough."

${ }^{16}$ Ibid.

${ }^{17}$ McClelland, "Contesting Destruction, Constructing Heritage," 297.

${ }^{18}$ Ward, "Soviet Communism," 508.

${ }^{19}$ Cited in O'Neill, The Autobiography, 47.
} 
relating to place contestation is an impulse motivating much planning history and such curiosity underpinned the archival research informing this paper. ${ }^{20}$

\section{The city of Armagh}

Armagh occupies a strategic position in the drumlin landscape of south Ulster, the northernmost of the four historic provinces of Ireland, and is located at a prominent crossing point over the River Callan where several important routes historically converged (see Figure 10 for Armagh's geographic proximity to Belfast). It is considered the oldest settlement in Ireland, ${ }^{21}$ and its close association with Saint Patrick supported its pre-eminence as an ecclesiastical centre from the late-seventh century onwards. ${ }^{22}$ As such, Armagh suffered extensive destruction on numerous occasions, including during the sixteenth century following the dissolution of the monasteries by Henry VIII and the subsequent Elizabethan-era military campaigns by the English Crown aimed at quelling dissention in Ireland. The present-day Church of Ireland (Protestant) Cathedral, whose foundation dates from the mid-thirteenth century, is the oldest structure still surviving, albeit much of its visible fabric dates from 'restoration' in the 1830s. ${ }^{23}$ However, the built environment of Armagh was predominantly constructed from the late-eighteenth century onwards under the patronage of the Primates of the Established Protestant Church, particularly Archbishops Robinson and Lord John George Beresford. ${ }^{24}$ The most notable buildings completed in this period are illustrated on O'Hagan's map of 1851 (Figure 1), including the Primatial Palace, Court House, Observatory, Public Library, and Royal School. A series of Georgian terraces and spaces were also laid out at this time, with the Mall remaining an important public space and 'one of Ireland's most attractive urban parks'. ${ }^{25}$ A Roman Catholic Cathedral was begun in 1840 in the aftermath of Catholic Emancipation in Ireland, although work was delayed by the Great Famine and the death of the original architect, Thomas Duff. This imposing twin-spired cathedral was finally completed - at least externally - to the designs of James Joseph McCarthy in 1873, and it - together with the Protestant cathedral - continues to dominate the skyline (Figure 2). Following the Partition of Ireland in the 1920s, six of the nine Ulster counties formed Northern Ireland, including County Armagh, while three other counties, Donegal, Cavan, and Monaghan, were incorporated into the Irish Free State and subsequently the Republic of Ireland from 1949. The emergence of two distinct political jurisdictions on the island, however, did not significantly impact on Armagh's status as an ecclesiastical centre.

In spite of Armagh's connection to a burgeoning railway network in the nineteenth century, when it was home to a handful of linen spinning mills and weaving factories, it never developed as an industrial settlement in the way that Belfast did so spectacularly. Indeed, the population of Armagh in 1961 was $10,062 .{ }^{26}$ Rather, its ancient history, ecclesiastical associations, small size, and non-industrial character situate it in the Northern Ireland-equivalent category of the English 'jewel cities' discussed by Pendlebury and Strange, such as Bath, Chester, and York. ${ }^{27}$ For instance, the 1947 report of the Planning Advisory Board on Amenities in Northern Ireland, The Ulster

\footnotetext{
${ }^{20}$ Tewdwr-Jones, Urban Reflections, 245.

${ }^{21}$ Lynn and McDowell, "The Oldest City in Ireland," 57-61.

${ }^{22}$ McCullough and Crawford, Armagh.

${ }^{23}$ See Mulligan, South Ulster, 98-9.

${ }^{24}$ Weatherup, The Buildings of Armagh.

${ }^{25}$ Ibid., 127.

${ }^{26}$ McCullough and Crawford, Armagh, 9.

${ }^{27}$ Pendlebury and Strange, "Centenary Paper."
} 


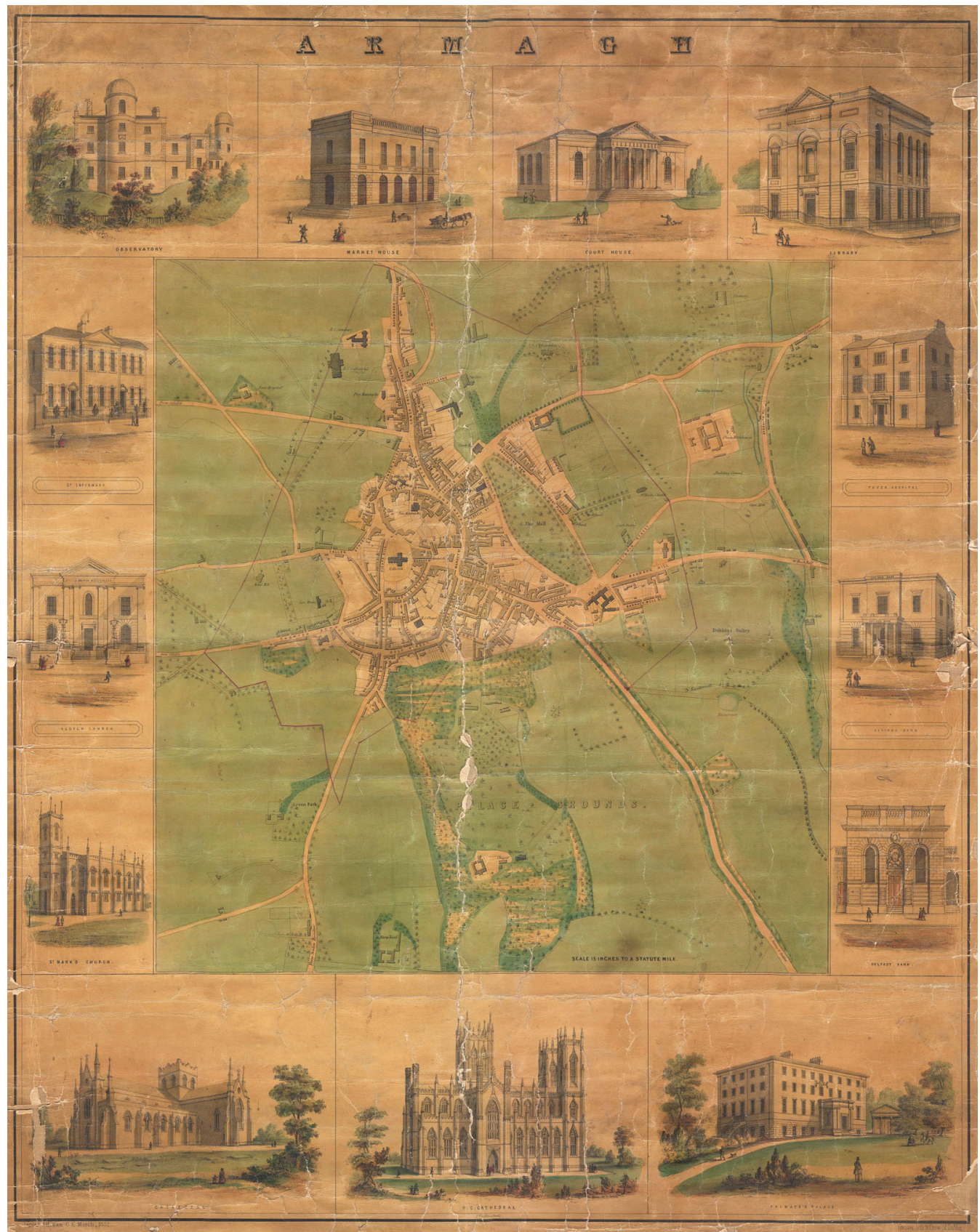

Figure 1. O'Hagan's 1851 map indicates many of the most prominent institutional and religious buildings in Armagh. Reproduced with the permission of the deputy keeper of the records, public record office of Northern Ireland (D2671/4).

Countryside, positively referenced the preservation of groups of buildings in Armagh. ${ }^{28}$ In the early 1960s, Matthew noted that Armagh, Carrickfergus, Enniskillen, and Londonderry 'are probably the

${ }^{28}$ Planning Advisory Board, The Ulster Countryside, 29. 


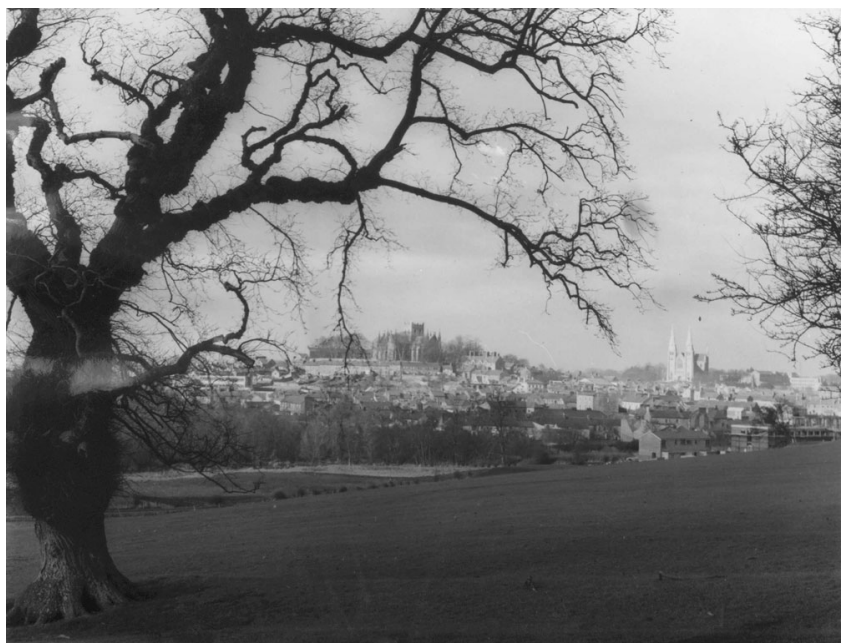

Figure 2. The Protestant (centre) and Catholic (twin-spired, left) cathedrals dominating the Armagh skyline in the early 1960s. Reproduced with the permission of the deputy keeper of the records, public record office of Northern Ireland $(\mathrm{CAB} / 9 / \mathrm{D} / 87 / 1)$.

most rewarding' in Northern Ireland in respect of their touristic and recreational potential due to their historic character, whereas Belfast was not considered 'attractive to tourists' ${ }^{29}$ The growing interest in Armagh's architectural heritage in the 1960s is not wholly surprising, therefore, given its history and characterful appearance. However, adapting such places to the growing demands of modernity increasingly challenged those in positions of authority, and the potential conflict between preservation and renewal was recognized by the local architect-planner Philip Bell in his 1944 Planning for Armagh report, which was highly interventionist in nature, envisioning new roads and the demolition of older housing, but also recognized the city's picturesque qualities and many buildings of architectural merit. ${ }^{30}$ In the absence of an appropriate legislative framework, little statutory protection was afforded to Armagh's built environment by the early 1960s, fuelling concerns within civil society that significant buildings could be lost and prompting calls for appropriate action.

\section{The NT and Armagh}

The Northern Ireland Committee of the NT was established in 1936 to manage the local affairs of the organization. The committee operated relatively autonomously from the centralized structures in England and Wales under the provisions of the NT Act (Northern Ireland) 1946, and closer financial integration with the NT's headquarters was only implemented from the mid-1960s. ${ }^{31}$ The membership of the Northern Ireland Committee, as in England and Wales, broadly consisted of an elite of 'aesthetically inclined aristocrats', distinguished experts, members of the professional classes, and other influential people educated in artistic and cultural matters. ${ }^{32}$ Lord Antrim was the Chairman of the Northern Ireland Committee from 1947 until October 1964, and was elevated in 1965 to the

\footnotetext{
${ }^{29}$ Matthew, Belfast Regional Survey, 226, 237.

${ }^{30}$ Bell, Planning for Armagh.

${ }^{31}$ Gallagher and Rogers, Castle, Coast and Cottage.

${ }^{32}$ Nixon, "Trouble at the National Trust," 531.
} 
chairmanship of the NT, UK-wide, at a crucial time in the history of the organization. Indeed, his experience of overseeing the devolved Northern Ireland Committee conceivably informed the 'regionalization' and other reforms that were implemented following the 1968 Benson Report. ${ }^{33}$ Certain other characteristics of UK associational culture are likewise evident in Northern Ireland in the 1960s, including the cross-over in membership between different organizations and a certain porosity between civil society and government. ${ }^{34}$ For instance, a key individual on-the-ground during Lock's survey, George Paterson, was a full-time curator of the Armagh County Museum and member of the NT's Northern Ireland Committee. The NT's regional secretary, John Lewis-Crosby, was likewise a member of the Ancient Monuments Advisory Council (AMAC), while Richard Rogers, a senior civil servant 'responsible for preparing and implementing Northern Ireland's first conservation legislation', served on the Committee for some 40 years. ${ }^{35}$

The NT's commissioning of the Armagh inventory was prompted by a series of local and regionally significant issues, some of which were specific to experimentation concerning its role as a conservation organization, while also implicated within wider advocacy debates over legislative and institutional change. Firstly, pressure for central area redevelopment was growing in the early 1960s, and urban areas in Northern Ireland proved no exception to this broader UK trend. ${ }^{36}$ In Armagh, the Northern Ireland Housing Trust was progressing a 'slum clearance' programme in the Callan Street area in 1962-1963, while tentative proposals were contemporaneously emerging for the construction of a ring road skirting the southern edge of the historic Mall, with further redevelopment areas under consideration by the Urban District Council. ${ }^{37}$ Thus, threats to the local built environment were gaining momentum with the active support of central and local government, potentially impacting on buildings and places valued by members of the Northern Ireland Committee. Indeed, the organization observed as early as 1959 that the 'face of Northern Ireland is changing fast', and Lord Antrim visited Armagh that same year where he saw 'several interesting buildings and blocks of property which might be considered worthy of preservation' ${ }^{38}$ Although nothing immediately came of this visit, Lewis-Crosby evidently kept a watching brief on developments and wrote to Paterson at the County Museum in January 1963 enquiring about 'press comments recently that there is some proposal afoot to re-develop the centre of Armagh' ${ }^{39}$

A second critical factor heightening the sense of threat towards Armagh's built environment concerned the very different legislative and institutional environment to Great Britain. ${ }^{40}$ No equivalent to the English Town and Country Planning Act 1947 existed at the time of the Armagh survey; hence no such statutory process for the 'listing' of buildings of architectural or historic interest existed. In theory, the 1926 Ancient Monuments Act in Northern Ireland (and its 1937 successor Act of the same name) could be applied to 'schedule' structures of any age. However, by the early 1970s, this was only used in four instances, and one of these involved the 'test case' of a Victorian-era warehouse in Belfast which was swiftly demolished once the authorities declined to follow through with the serving of a Preservation Order. ${ }^{41}$ In addition to the virtual absence of legislative protection, inventorying processes

\footnotetext{
${ }^{33}$ Ibid., 529-50.

${ }^{34}$ See, for example, Hewitt, "Associational Culture," 590-606; and Hewitt and Pendlebury, "Local Associations and Participation," $25-44$.

${ }^{35}$ Buchanan, "Foreword," ix.

${ }^{36}$ Pendlebury and Strange, "Centenary Paper,"; Smith, "Central Government and Town Centre," 217-44.

${ }^{37}$ See Northern Ireland Housing Trust, Annual Report; and "The Changing face of Armagh," The Armagh Guardian, 10 May 1962.

${ }^{38}$ National Trust, Annual Report [1959], 2. Public Record Office of Northern Ireland (henceforth PRONI), D3839/1/1/3, National Trust Finance and General Purposes Committee Minutes (Northern Ireland region), 13 January 1959.

${ }^{39}$ Armagh County Museum (henceforth ACM), Letter File 30, Lewis-Crosby to Paterson, 2 January 1963.

${ }^{40}$ See Hendry, "Conservation in Northern Ireland" and McClelland, "Contesting Destruction, Constructing Heritage."

${ }^{41}$ lbid.
} 
for architectural heritage were also highly inadequate, a particularly acute problem given the centrality of the inventory to conservation policy and practice. The NT initially contemplated producing a regional 'survey of houses of architectural or historic interest' for its own use, with no specific focus on Armagh. ${ }^{42}$ It also communicated with the Northern Ireland Archaeological Survey calling for the speeding up of inventorying processes and requesting their surveys to be 'completed on the lines of that undertaken ... in Great Britain under the Town and Country Planning Act'. ${ }^{43}$ However, the slow pace of the Survey's work and its marginal interest in architectural heritage (as opposed to ancient monuments) were deemed problematic by the NT, triggering moves towards the commissioning of Lock. Contemporaneous with the NT's interest in Armagh, the future of industrial and Victorian buildings in Belfast was being discussed by the AMAC, and the cross-over in membership between the various civil society groups ensured a common awareness of regional developments. ${ }^{44}$

\section{Commissioning the Armagh inventory}

From the outset the NT was concerned with attracting an 'outstanding consultant' to undertake the Armagh survey. ${ }^{45}$ Two important and related issues required addressing at an early stage: firstly, the identification and appointment of the consultant and, secondly, determining how (and by whom) the work would be financed. Concerning the former, a number of prominent UK-based consultants were initially recommended to the Northern Ireland Committee by Lord Rosse in consultation with the NT's Historic Buildings Committee in London, who suggested Lock, and, in the event of his unavailability, Hugh Casson or Geoffrey Jellicoe. ${ }^{46}$ Lock's post-war reconstruction plans were not particularly known for their attentiveness to urban conservation, with that for the Hartlepools, for instance, making no specific mention of older buildings, in contrast to several others produced in the 1942-1952 period. ${ }^{47}$ However, Lock was responsible for preparation of the redevelopment plan for the historic centre of the English Cathedral City of Salisbury in 1963, winning a related public enquiry, and it was his work there that was favourably referenced following the announcement of his Armagh commission. ${ }^{48}$ The Historic Buildings Committee considered Lock best placed to undertake the survey, and Lewis-Crosby corresponded with, and then 'interviewed' him in London in November $1963 .{ }^{49}$ Lock visited Northern Ireland for the first time the following month, in what could be characterized as a 'Geddes-style reconnaissance visit', and arrangements were then made for his return in February $1964 .^{50}$

Financing the survey proved more problematic than the identification of a well-known consultant. The driving force behind the NT's efforts, Lewis-Crosby, recognized that the organization would potentially have to bear the costs, but he was initially optimistic that a company such as Shell would agree to at least partially fund the survey. ${ }^{51}$ The Northern Ireland Committee, however, was more cautious and sought to ensure that any associated costs were borne in stages as funding permitted. ${ }^{52}$

\footnotetext{
${ }^{42}$ PRONI, D3839/1/1/3, National Trust Northern Ireland Committee Minutes, 15 November 1960.

${ }^{43}$ PRONI, D3727/H/4/1, National Trust Northern Ireland Committee Minutes, 11 November 1961.

${ }^{44}$ PRONI, FIN/17/1F/20/2, Ancient Monuments Advisory Council Minutes, Belfast Survey Memorandum, 16 October 1963.

${ }^{45}$ PRONI, D3727/H/4/1, National Trust Northern Ireland Committee Minutes, 9 July 1963.

${ }^{46}$ PRONI, D3839/A/1/6, National Trust Executive Committee Minutes (Northern Ireland region), 8 October 1963; ACM, Letter File 38, LewisCrosby to Paterson, 22 October 1963.

${ }^{47}$ Larkham, "The Place of Urban Conservation," 303.

48" $£ 300$ Wanted to Save Armagh's Old-world Charm," The Armagh Guardian, 30 April 1964.

${ }^{49}$ PRONI, D3839/A/1/7, National Trust Executive Committee Minutes (Northern Ireland region), 10 December 1963.

${ }^{50}$ See Glendinning, Modern Architect, 327.

${ }^{51}$ ACM, Letter File 37, Lewis-Crosby to Paterson, 20 September 1963.

${ }^{52}$ PRONI, D3839/A/1/7, National Trust Executive Committee Minutes (Northern Ireland region), 10 December 1963.
} 
Indeed, when Esso turned down a request for $£ 500$, instead offering $£ 50$ sponsorship, the Committee was prepared to pull the plug entirely on the survey, forcing the postponement of Lock's proposed visit to Armagh in February 1964. ${ }^{53}$ In response to this setback, Lewis-Crosby employed a more public-facing approach to raising the remainder of the target amount of $£ 300$, appealing directly in writing to businesses with local interests, including through the Armagh Chamber of Commerce, details of which were relayed via the council and featured in several local newspapers. ${ }^{54}$ This appeal was a success, and Lewis-Crosby was able to report by late April 1964 that he was $£ 40$ short of the required sum, and was sufficiently confident to make arrangements for Lock's return in June. ${ }^{55}$ In any event, the council pledged to make up any shortfall, in addition to offering 'in kind' contributions through the provision of office space, maps, and other important incidentals. ${ }^{56}$ Similarly, the Curator of the County Museum freely provided his time and expertise, with Lewis-Crosby even intimating that much of the Armagh list 'will be largely Mr Paterson's' ${ }^{57}$ Nonetheless, these difficulties undoubtedly exposed some of the problems associated with a civil society organization pursuing what had long been a statutory inventorying obligation elsewhere in the UK, and the financial constraints clearly impacted on the production values of the final report.

\section{'Surgery or Butchery?'}

Lock's completed report was modest in size (12 pages), low in its production values (for instance, containing no photographs), and had little by way of narrative and architectural description. The inventory listed 153 buildings and groups of buildings predominantly located within the centre of Armagh (135 within central area, and 18 entries from the surrounding countryside), each categorized according to one of three grades corresponding with the colour coding on a loose-leaf accompanying map (Figure 3). Those marked in red were considered 'first grade ... buildings of great architectural distinction which should, in no circumstances, be demolished'. Those in blue were second grade and deemed 'important architecturally and should be conserved even at the cost of considerable expenditure'. The third category, identified in green, were 'worthy of preservation' and, although some 'could not, by themselves, be described as architecturally distinguished', they contributed 'to the style and character of the street as a whole'. ${ }^{58}$ In terms of their relative frequency, 42 of the entries related to category I, while categories II and III accounted for 55 and 54 entries, respectively. Two entries were uncategorized, although the County Museum is coloured red on the map, indicating a category I status. The terse notes accompanying some of the entries identify the original architect or building date where known or noteworthy, sometimes also remarking on its state of repair or making suggestions as to desirable improvements, particularly in instances were inappropriate alterations were deemed aesthetically problematic.

The category I entries were predominantly the major ecclesiastical, institutional, banking, and educational buildings dating from the Georgian-era, mostly standalone and located in prominent positions. This grading extended to embrace the fine Georgian terrace facing the Mall at 1-5 Charlemont Place, the Primatial Palace and Chapel, Public Library, and County Museum (Figures 4-7). The category II and III entries, by contrast, largely comprised terraces and groups of buildings

\footnotetext{
${ }^{53}$ PRONI, D3727/H/4/1, National Trust Northern Ireland Committee Minutes, 10 March 1964.

${ }^{54}$ See "300 Wanted to Save Armagh's Old-world Charm" and "£300 for Listing Valuable Buildings," The Ulster Gazette, 9 April 1964.

${ }^{55}$ PRONI, D3839/B/24, Lewis-Crosby to Earl of Antrim, 24 April 1964.

${ }^{56}$ Ibid.; Lock, The City of Armagh.

${ }^{57}$ PRONI, D3839/B/24, Lewis-Crosby to Earl of Antrim, 17 June 1964.

${ }^{58}$ Lock, The City of Armagh, foreword.
} 


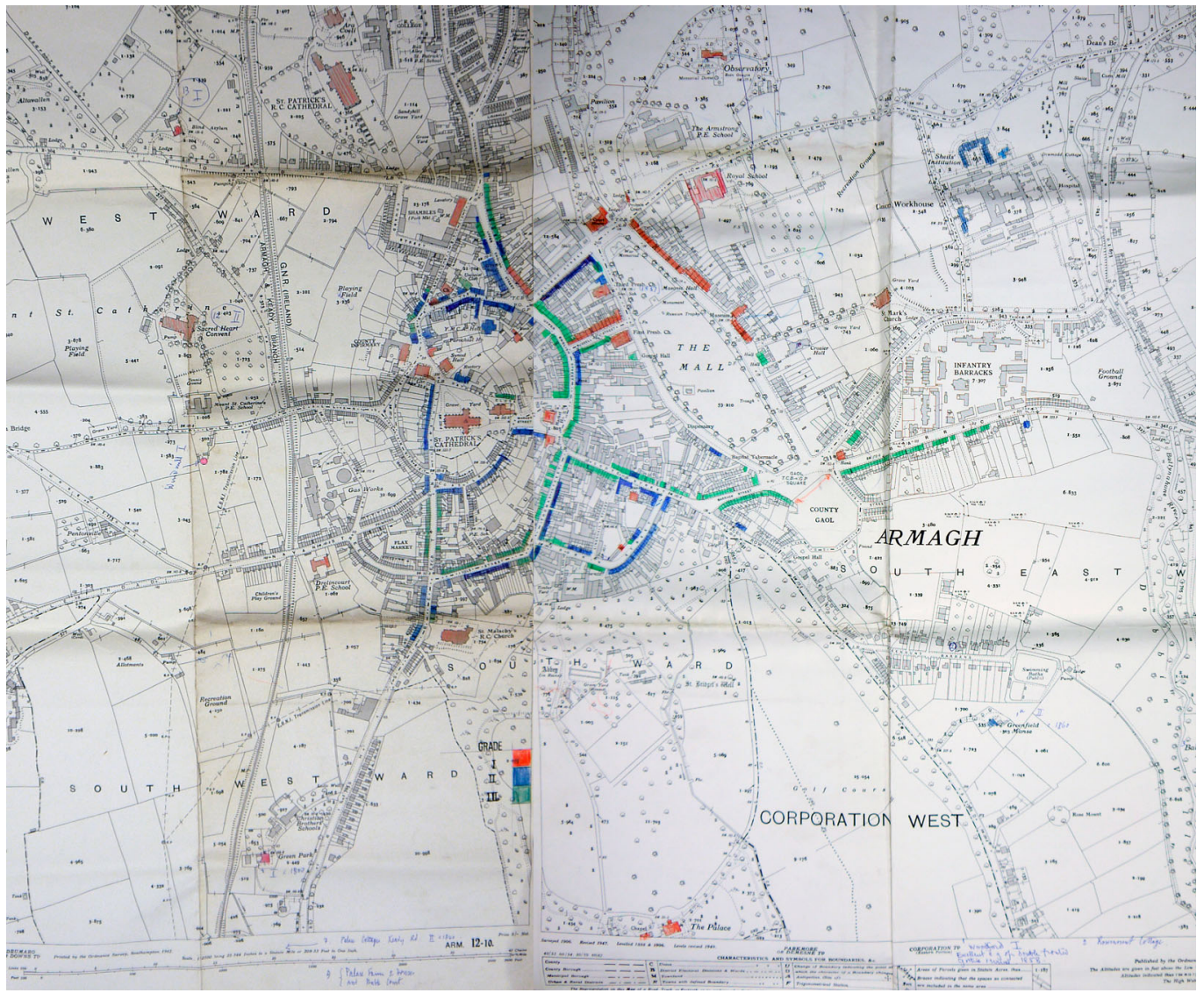

Figure 3. Lock's annotated and colour-coded map of Armagh. Reproduced with the permission of the University of Westminster Archive (MLA 9.28). Crown copyright 2016.

fronting the principal thoroughfares approaching the centre, including some of the streets encircling the hill upon which the Church of Ireland Cathedral is sited. In terms of their usage, these latter categories generally comprised houses, shops, public houses, hotels, offices, and other commercial buildings, including a mill facing the Mall and a stone warehouse occupying a large frontage on Dobbin Street, indicating a certain regard for 'industrial archaeology' - the UK's first conference on industrial archaeology took place in 1959 under the auspices of the Council for British Archaeology. ${ }^{59}$ However, aside from these latter two structures, several market and farm buildings, and a prominent windmill stump on the western fringes of the city, few utilitarian buildings were identified, partly reflecting the non-industrialized character of Armagh and greater appreciation then afforded to Georgian architecture.

Several mid to late nineteenth-century ecclesiastical and institutional buildings are included in Lock's inventory. However, Victorian and Edwardian-era buildings omitted from any categorization include the bay-windowed terraces at Hartford Place and 12-36 Victoria Street, which would subsequently be statutorily protected by the government under the process commonly referred to in the UK as 'listing'. Such an omission was not altogether surprising in the mid-1960s given that 


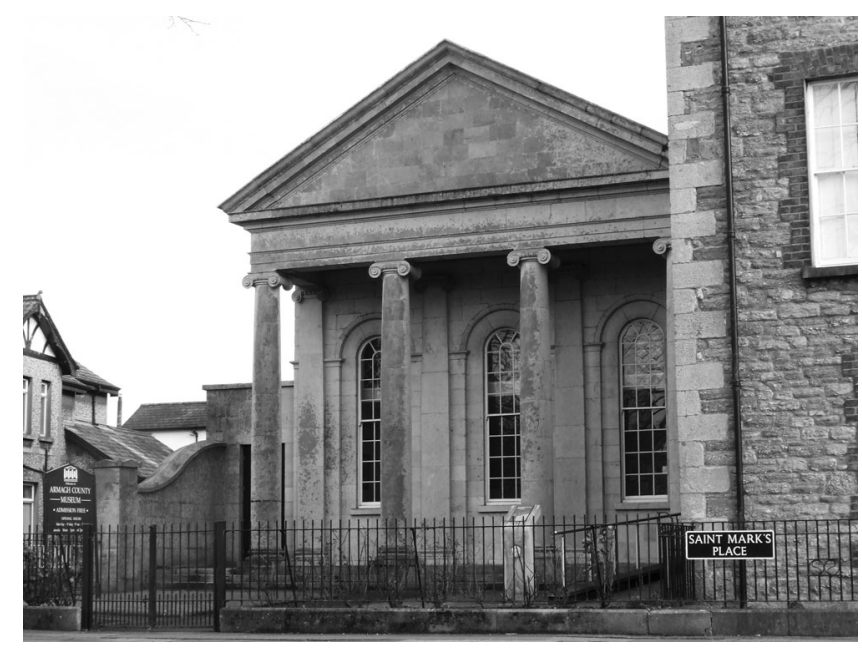

Figure 4. Armagh county museum. Source: Author.

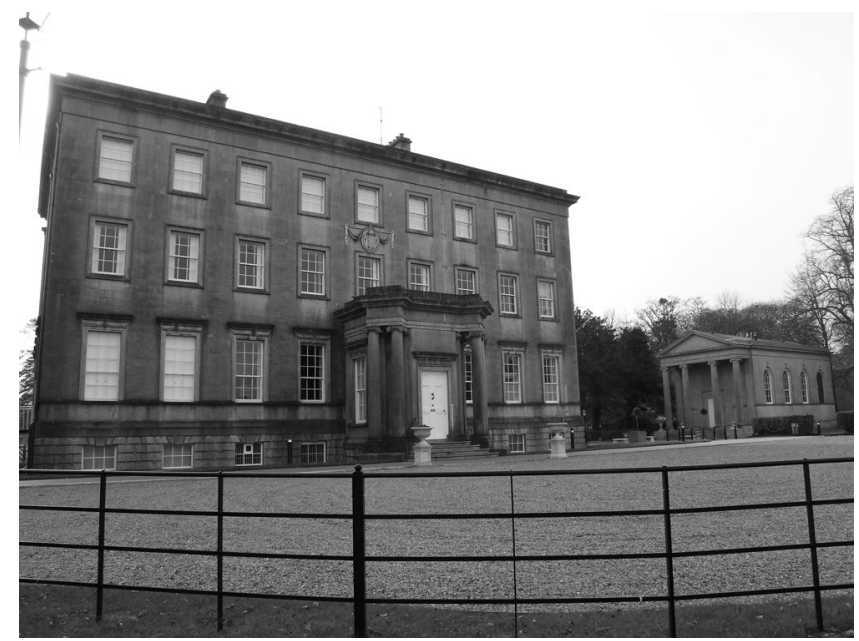

Figure 5. Former Primatial Palace and chapel (now owned by Armagh City, Banbridge and Craigavon Borough Council). Source: Author.

Victorian buildings had only become a serious official concern a few years previously in England with the establishment of a sub-committee by the Ministry of Housing and Local Government in 1959 to look into the issue of their protection, and their group value was hardly likely to be recognized in Armagh when surrounded by fine Georgian buildings. ${ }^{60}$ Nonetheless, the growing importance of area conservation in the early 1960s and the necessity to consider the group value of older buildings and townscapes are clearly evident from Lock's inventory, and his advice followed the spirit of the UK government guidelines which stressed the importance of conserving the character of towns. ${ }^{61}$ Individual monuments, Georgian terraces, public spaces, and the 'artisan' vernacular buildings that comprised much of the physical fabric of urban places, therefore, were increasingly

\footnotetext{
${ }^{60}$ Harwood, "Keeping the Past in England," 671-82.

${ }^{61}$ See Delafons, Politics and Preservation, 95-101.
} 


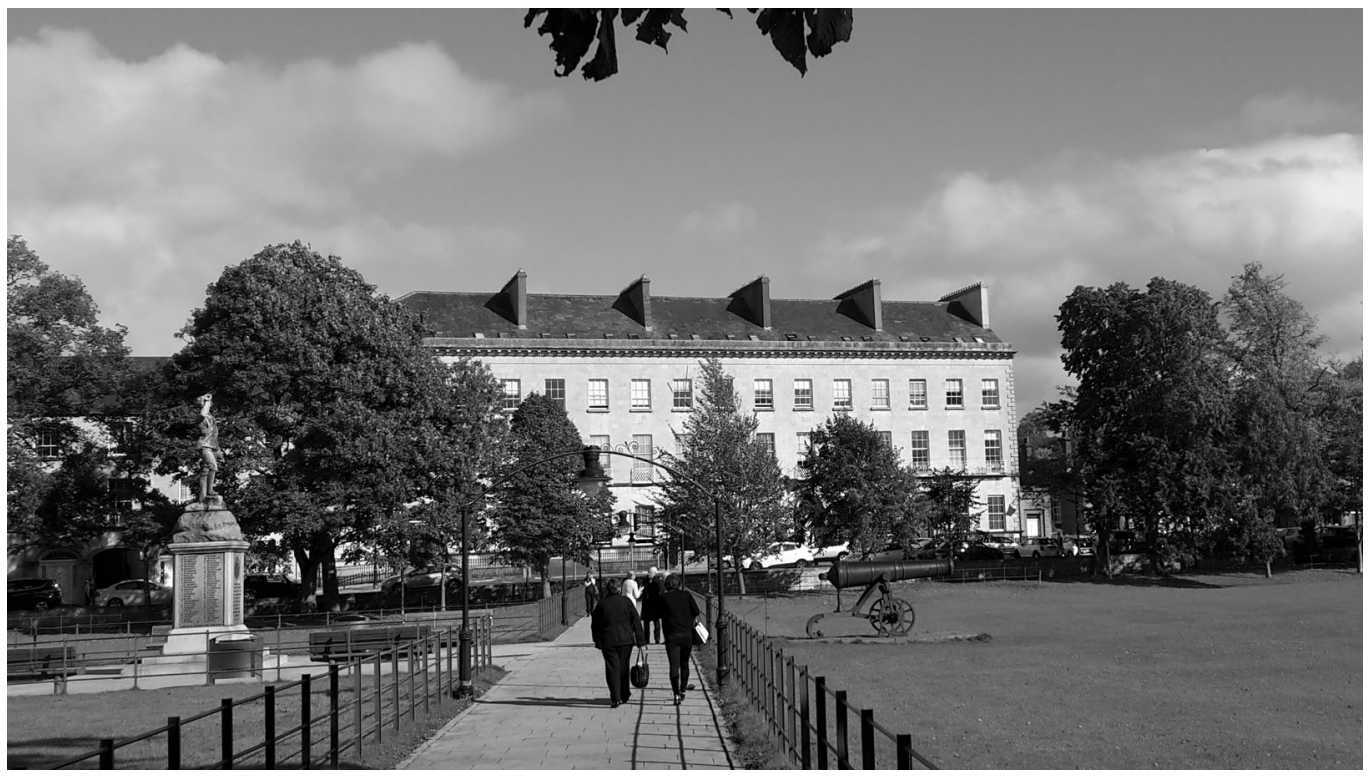

Figure 6. 1-5 Charlemont place viewed from the mall. Source: Author.

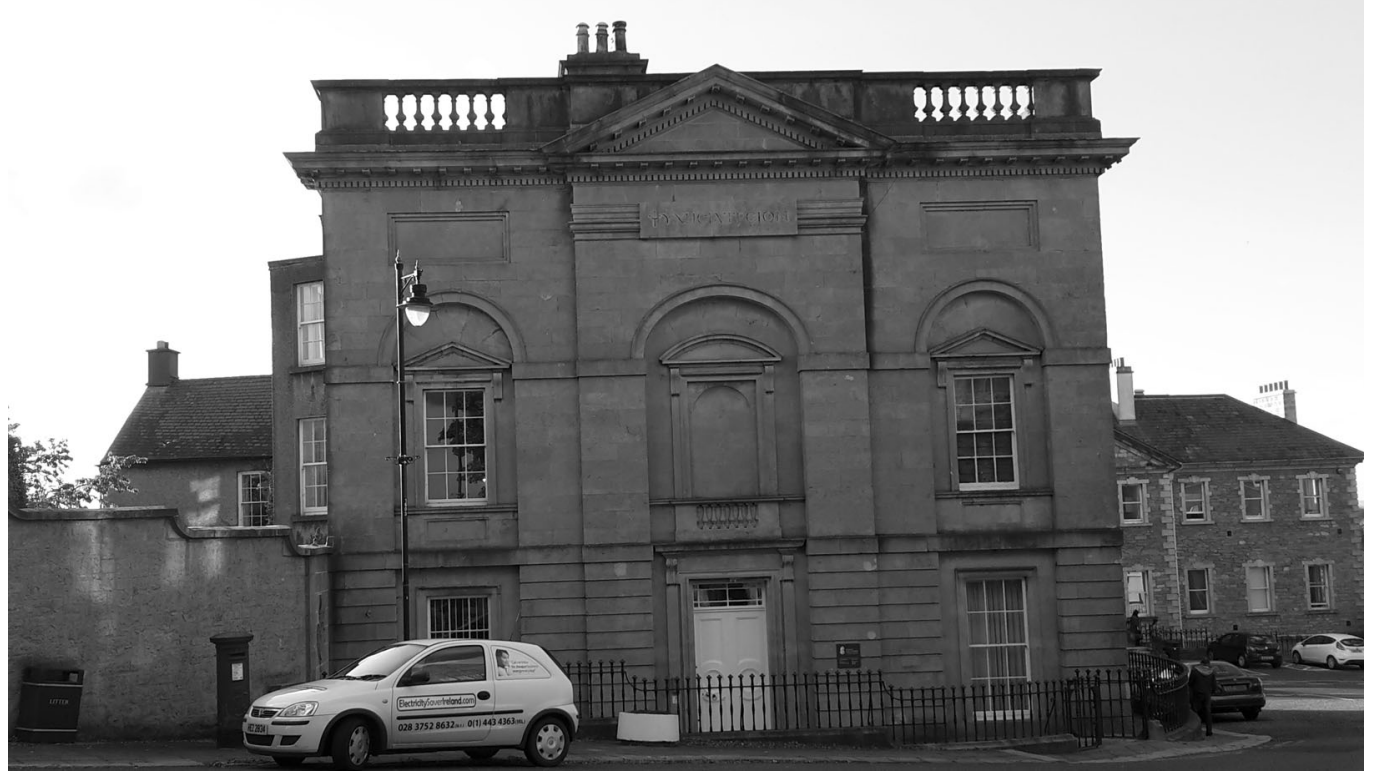

Figure 7. Armagh public library. Source: Author.

seen as part of a wider historic ensemble. Ensuring their protection was a different matter and cities such as Bath witnessed high-profile battles over the survival of minor Georgian heritage even after the introduction of conservation area controls in England through the 1967 Civic Amenities Act. ${ }^{62}$

\footnotetext{
${ }^{62}$ Pendlebury and Strange, "Centenary Paper," 369.
} 


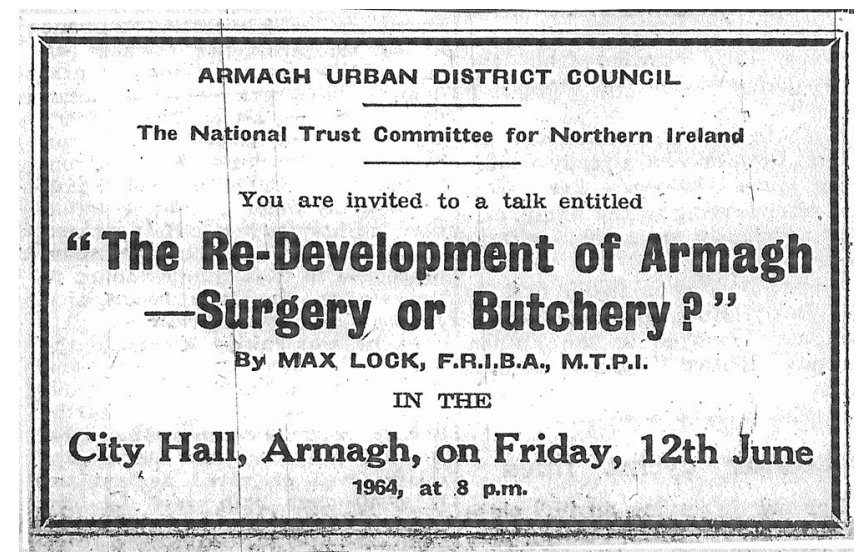

Figure 8. The advertisement for lock's 'surgery or butchery' lecture in The Armagh Guardian newspaper, 11 June 1964.

Lock's inventory at the very least disclosed a sensitivity towards group value and the urban vernacular buildings of Armagh, albeit a greater number of such structures are recognized and protected today than was envisaged in the 1960s.

Closely bound up with this unofficial ascription of heritage values was consideration of the degree of permissible intervention into Armagh's historic fabric under future redevelopment. Lock's foreword to the inventory makes clear where demolition and new development would be appropriate, with the so-called 'backlands' identified as a largely 'obsolete waste of badly arranged' and 'semiderelict' buildings. The backlands presented opportunities to accommodate a variety of new uses, including extensions and service access to existing shops, car parking 'to relive the narrow congested streets', and potentially sites for new centrally located housing. The latter was also seen as a way of dealing with the double-imperative of preventing further urban sprawl while protecting views into the historic city from being further 'spoiled by red brick housing schemes' ${ }^{63}$ More importantly, the philosophy guiding Lock's recommendations was articulated in a public lecture that he gave at Armagh City Hall in June 1964 - 'The Re-Development of Armagh: Surgery or Butchery?' (Figure 8) - and the 'conservative survey' approach that he advocated, typically consisting of a 'cautious, piecemeal, place-sensitive formula', was reported at length in the local press. ${ }^{64}$ For instance, Lock's lecture was infused with Geddesian-inspired language and sensitivity towards planning for character in historic towns, which was not altogether surprising given that Lock is considered the 'most Geddesian' of the post-war planners in the UK. ${ }^{65}$ By way of illustration, Armagh was described as a 'living organism', which required prior survey and diagnosis before 'surgery', while Lock emphasized that 'instead of pulling down old buildings which give the ancient city character', they should be given a 'face and body lift'. ${ }^{66}$ As Glendinning points out, many prominent consultants in the 1960s supported conservative surgery in dealing with historic settlements, and this approach also found favour with conservationists in Northern Ireland. ${ }^{67}$

\footnotetext{
${ }^{63}$ Lock, The City of Armagh, foreword.

${ }^{64}$ Glendinning, The Conservation Movement, 175.

${ }^{65}$ Meller, "Gender, Citizenship," 27.

${ }^{66}$ Cited in "'Face and Body Lift'," The Ulster Gazette, 18 June 1964.

${ }^{67}$ Glendinning, The Conservation Movement. See McClelland, "Contesting Destruction, Constructing Heritage," 116.
} 


\section{Media attention and place promotion}

Lock's work provided a focal point for discussions surrounding a multiplicity of local and regional issues. It was also primarily intended as a 'public relations exercise' ${ }^{68}$ To this end, the process was undoubtedly a marked success for the NT, and the local press published several dozen articles prior to, during, and after Lock's visits to Armagh, with his presence in the city in 1964 identified by The Armagh Guardian newspaper as one of the highlights of the year (Figure 9). More prominently, the production of the inventory featured several times in the Belfast Telegraph, one of the largest regional newspapers at the time, and a favourable editorial linked it with the wider need for planning legislation:

The threat of the bulldozer to old houses in Armagh is a sharp reminder that Northern Ireland lags behind Great Britain in protecting houses of historic importance or architectural merit ... The coming legislation on planning will be an opportunity to get into line with Great Britain by making the comprehensive listing of important buildings obligatory. With redevelopment going ahead fast in all areas, there is no time to be lost. ${ }^{69}$

The editor-in-chief of the Belfast Telegraph, John Sayers, was evidently well briefed on the context and the demands of conservationists, particularly as he himself was a member of the Northern Ireland Committee of the NT and was specifically thanked for this editorial at a subsequent meeting. ${ }^{70}$ Sayers was also a close confidant of O'Neill and a keen supporter of many of his reform initiatives, ensuring that he was a key ally and popularizing voice for conservation within the media. ${ }^{71}$ Although the editorial in June 1964 assumed the impending progression of legislation, the negative political reaction to a series of planning-related announcements soon overshadowed the impetus towards reform.

The fact that the media was highly receptive to planning stories and their attendant controversies in the mid-1960s, in part, reflected a rising chorus of criticism emanating from local authorities. For example, in response to the Matthew Plans multivariate recommendations on planning, physical development, and local government, Belfast Corporation sought to rally opposition to the 'death blow' to the city that they were asserted to represent. ${ }^{72}$ The prospect of change on the scale proposed was acutely felt by councillors in Armagh, and for good reason. Not only did they represent a challenge to Armagh's status as an administrative centre, but also the functional responsibilities of the Urban District Council, and, at worst, the council's very existence under rationalization. Followup proposals to the Matthew Plan did little to assuage these concerns. The Department of Health and Local Government's White Paper in 1964 on The Administration of Town and Country Planning in Northern Ireland proposed the creation of a centralized planning authority, which, in the words of Mulholland, would 'relieve local councils of arduous planning tasks' ${ }^{73}$ Such suggestions proved extremely unpopular, including amongst grassroots members of O’Neill's own party, and contributed to a burgeoning critique of his 'dictatorial manner'. ${ }^{74}$ In response, the Urban District Council sought to promote Armagh in both a positive and reflexively defensive way, utilizing its history and architectural distinctiveness as unique selling points.

\footnotetext{
${ }^{68}$ PRONI, D3839/B/24, Lewis-Crosby to Earl of Antrim, 17 June 1964.

69“"Historic Houses," Belfast Telegraph, 30 May 1964; "Trust Tries to Save Old Homes in Armagh Clearance," Belfast Telegraph, 29 May 1964.

${ }^{70} \mathrm{PRONI}, \mathrm{D} 3727 / \mathrm{H} / 4 / 1$, National Trust Northern Ireland Committee Minutes, 7 July 1964.

${ }^{71}$ Glendinning, Modern Architect, 331; McClelland, "Conservation at the Crossroads."

${ }^{72}$ lbid., 334.

${ }^{73}$ Mulholland, Northern Ireland, 73.

${ }^{74}$ Patterson and Kaufman, Unionism and Orangeism, 67.
} 


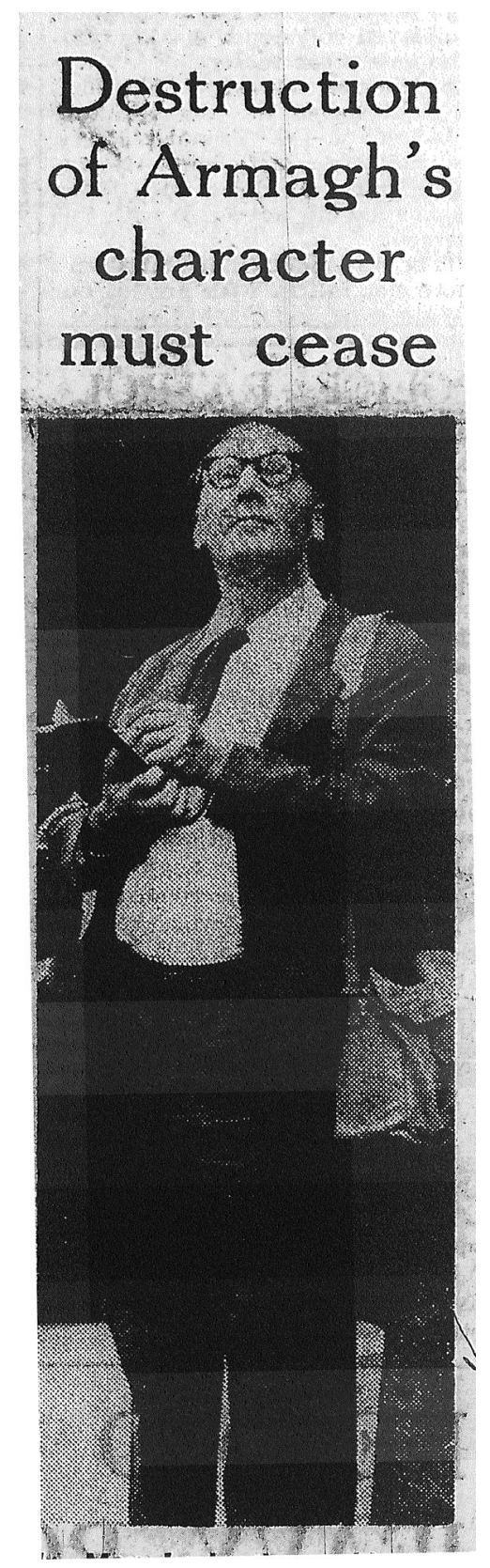

Figure 9. Lock in Armagh working on his inventory in June 1964: Source: The Armagh Guardian, 11 June 1964.

Fundamental to Armagh's future status was the implications arising from the key proposal of the Matthew Plan to create a 'New City' in County Armagh. The New City, initially earmarked to accommodate 100,000 by 1980 , was to be located a mere 10 miles from Armagh, between the towns of Portadown and Lurgan. Its close proximity, envisaged scale, and anticipated location for numerous educational, administrative, and other functions were undoubtedly causes for local 


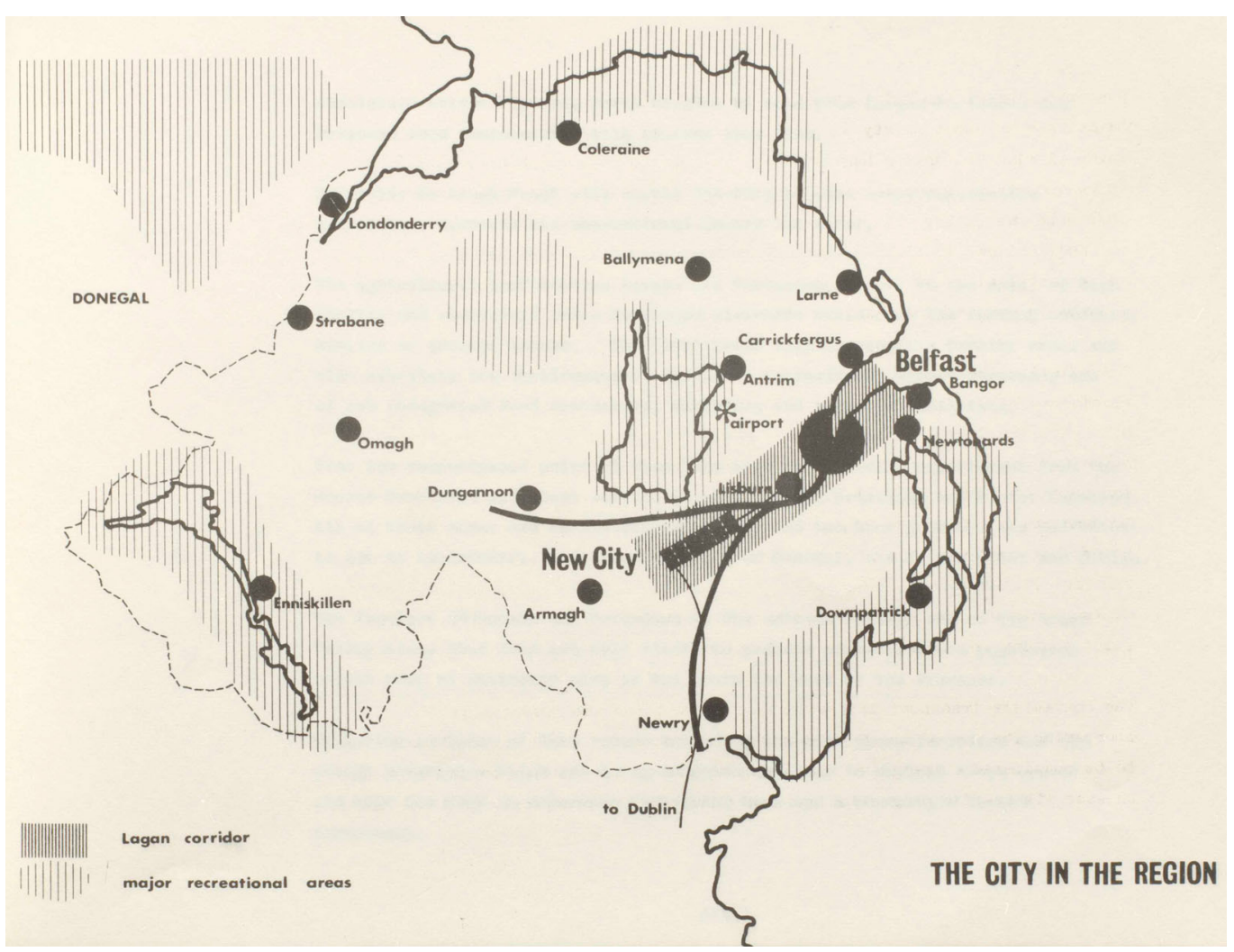

Figure 10. The conceptual location of the 'New City' in County Armagh within the 'Lagan corridor'. Source: New City Design Group, First report on the proposed new city, Co. Armagh.

alarm. ${ }^{75}$ The first report by the New City Design Group, published in late 1964, reaffirmed these concerns, illustrating the conceptual exclusion of Armagh from the economically dominant Belfast region and its bypassing by key transportation corridors (Figure 10) - Armagh had already lost its rail connection by $1957 .{ }^{76}$ Indeed, the report stated that nearby 'sphere of influence' towns like Armagh would essentially become commuter settlements for those employed in the New City. ${ }^{77}$ Thus, the abrupt resignation of the chief designer, Geoffrey Copcutt, the 'mercurial architect who ... masterminded the pioneering high-density megastructural design ... at Cumbernauld New Town' in Scotland, was welcomed in light of his assertion that Armagh become an administrative centre instead, prompting the local council to call the project into question. ${ }^{78}$ The controversial naming of the New City in early 1965 as 'Craigavon' - after James Craig (first Viscount Craigavon), 'the unionist hero and first Prime Minister of Northern Ireland' - further inflamed the situation with an 'incredulous' opposition at Stormont. ${ }^{79}$ Copcutt's resignation, for Glendinning, exposed the potential for controversies over planning to 'do damage to O'Neill's wider agenda of "reform,

\footnotetext{
${ }^{75}$ See PRONI LA/2/3/AG/72.

${ }^{76}$ New City Design Group, First Report.

${ }^{77}$ Ibid., 15.

${ }^{78}$ Glendinning, Modern Architect, 333. See also "New City Bombshell," The Armagh Guardian, 20 August 1964; and "No New City - Develop Other Towns," The Ulster Gazette, 10 September 1964.

${ }^{79}$ Mulholland, Northern Ireland, 51.
} 


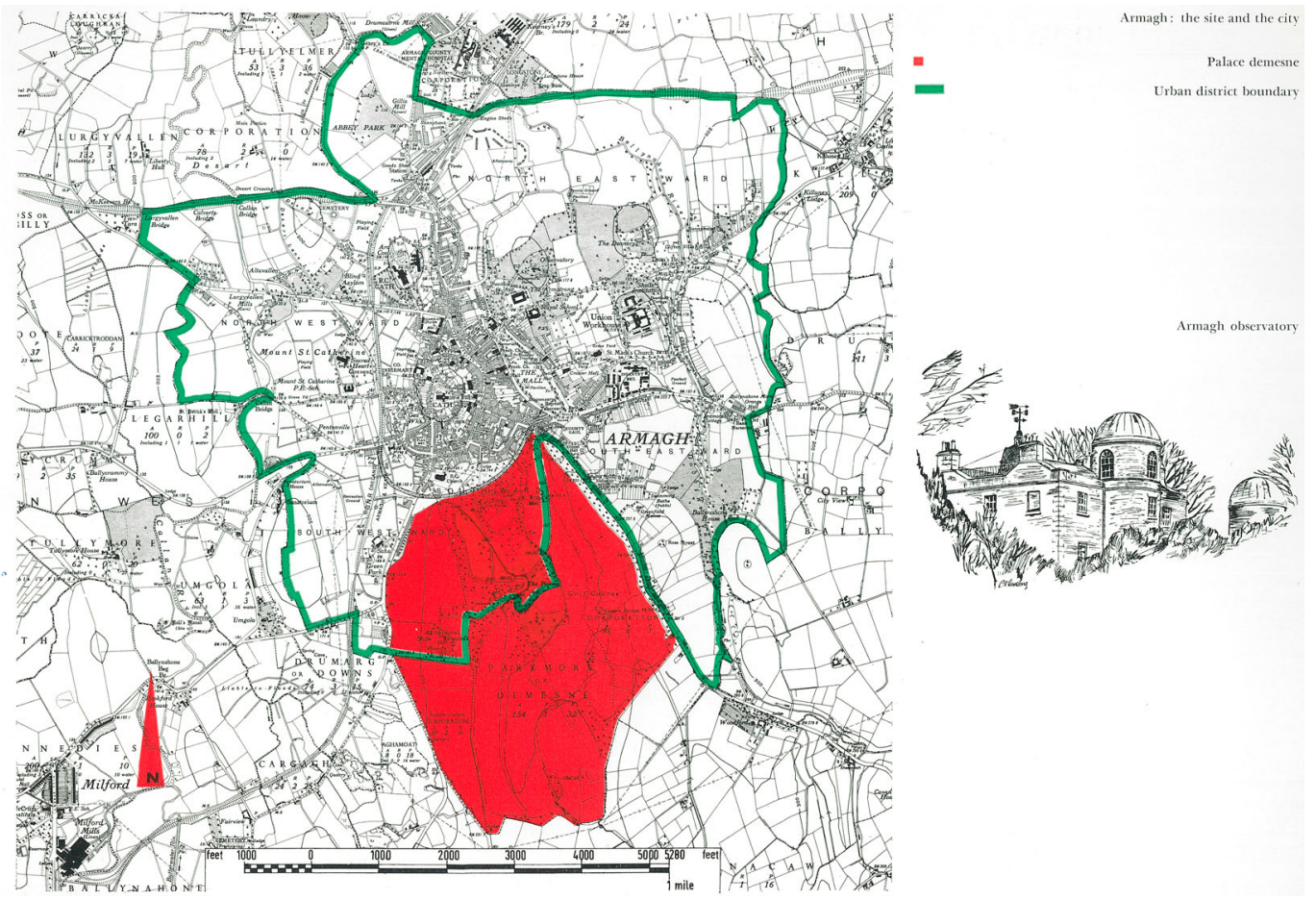

Figure 11. One of the proposed locations of a second university in Northern Ireland within the grounds of the Primatial Palace, Armagh. Source: Armagh county council, study and proposals by Armagh county council - a second university for Northern Ireland.

reconciliation, economic and social equality"', and Lock's work in Armagh emerged against an increasingly uncertain regional backdrop. ${ }^{80}$

In parallel with the acrimonious debate over planning, local government reform, and Craigavon, another controversy was brewing over the siting of a second university in Northern Ireland. This, too, would cause a political furore following the recommendations of the Lockwood Report in February 1965 and the decision to locate the second university in the 'protestant town of Coleraine', in the process ignoring the claims of the catholic majority, though Unionist controlled, Londonderry. ${ }^{81}$ The fallout from this snub meant that the claims of other unsuccessful places have largely been overlooked, including the representations made jointly by Armagh County Council and Armagh Urban District Council, who sought the development of a second university within the grounds of the Primatial Palace (Figure 11). From the point of view of Lock's survey, the arguments advanced in the councils' submission of January 1964 to the Lockwood Committee were rooted in the ecclesiastical and educational history of Armagh, which was contemporaneously reinforced by the existence of the County Museum and the aesthetic charms of its architectural heritage. ${ }^{82}$ The brochure referenced the ongoing work of the NT in advising the Urban District Council on conservation matters, which was liberally illustrated with sketches of well-known historic buildings. On his June 1964 visit, Armagh was endorsed by Lock as an 'ideal university site', a view supported by Hugh Casson

\footnotetext{
${ }^{80}$ Glendinning, Modern Architect, 337-8.

${ }^{81}$ Mulholland, Northern Ireland, 53.

${ }^{82}$ Armagh County Council, Study and Proposals.
} 
the previous year. ${ }^{83}$ By contrast, Matthew supported locating the second university in the New City, with backing from the Ministry of Health and Local Government and several government ministers. ${ }^{84}$ Armagh's architectural heritage was mobilized in a relatively superficial and uncoordinated manner by the Urban District Council. Nonetheless, deriving place promotional advantage from its cultural heritage represented an attempt at differentiating Armagh from the modernistic New City project.

\section{'Within-UK' diffusion of planning}

Northern Ireland is an interesting case of the diffusion of planning ideas and practices, albeit its 'within-UK' transference is more characteristic of international examples. Indeed, utilizing Ward's 'typology of diffusion' the development of planning in the region in the mid to late twentieth century most closely resembles 'undiluted borrowing', placing it within the same category as the 'white settled Dominions of the British Empire' such as Australia and Canada. ${ }^{85}$ Under this diffusion type, 'substantial packages of planning practice' are borrowed rather than 'individual ideas or innovations', while the receiving jurisdiction tends to have an 'underdeveloped indigenous planning movement' and 'a more general deference' to the ideas and practices emanating from the importing country. ${ }^{86}$ The development of a 'largely imitative' system of planning in Northern Ireland, as Hendry remarked, did not 'reflect the same process of gradual evolution' seen elsewhere in the UK, with changes in direction reflecting 'those occasions when ... legislators ... have attempted to catch up with British practices'. ${ }^{87}$ The logic of the 'parity' principle, whereby standards in social service provision between Great Britain and Northern Ireland were maintained through additional UK exchequer support for the latter, implied that the introduction of planning legislation was inevitable at some future point. ${ }^{88}$ However, this principle was not always pursued in practice in a number of controversial policy areas, including political rights, personal freedom, trade union affairs, the legal system, and social services. ${ }^{89}$ Although the 1972 Planning (Northern Ireland) Order resembled British precedents, the process leading to its introduction was delayed by political wrangling over local government reform and its consequences for Unionist patronage at the local level. ${ }^{90}$ The close coupling of planning and conservation in legislative terms inevitably meant that progress on the latter was dependent on advances with the former, irrespective of the cogent arguments for immediate action articulated by conservationists.

Although Northern Ireland lagged Great Britain in legislative and institutional terms in the early 1960s, the diverse mechanisms of diffusion ensured that informed opinion was at least up-to-date with the latest ideas. In particular, key personalities and 'foreign' consultants provided leadership in the transference of knowledge and learning to the local context, with the late adoption of planning having contributed to a dearth of qualified professionals in Northern Ireland. ${ }^{11}$ For instance, luminaries in the fields of planning and architecture who undertook commissions in Northern Ireland

\footnotetext{
${ }^{83}$ Lock cited in "Stop the Rot in Time!," The Armagh Guardian, 18 June 1964. Casson cited in "Armagh Has Ideal Varsity Site," The Armagh Guardian, 14 November 1963.

${ }^{84}$ Mulholland, Northern Ireland, 41. Matthew's support was indicated in "Matthew Wants the University in New City," The Armagh Guardian, 19 December 1963.

${ }^{85}$ Ward, "Re-examining the International Diffusion," 488.

${ }^{86}$ Ibid., 487.

${ }^{87}$ Hendry, "Conservation in Northern Ireland," 373.

${ }^{88}$ For a useful discussion of parity, see Birrell and Murie, Policy and Government, 280-82.

${ }^{89}$ Brett, "The Lessons of Devolution," 261-80. See also ibid.

${ }^{90}$ Murie, "Planning in Northern Ireland."

${ }^{91}$ See Newman, "A Short History."
} 
include Clough Williams-Ellis, William Davidge, and Robert Matthew. Colin Buchanan is another figure who visited the region at the height of his public-profile, with his Belfast lecture in 1963 inspiring one Urban District Councillor in attendance to propose a multi-level solution to Armagh's traffic problems. ${ }^{92}$ Furthermore, many 'alternative planning wizards', as they are characterized by TewdwrJones, frequently lectured to large local audiences, including John Betjeman, Ian Nairn, and, were it not for illness in 1963, the politician most associated with the rise (and fall) of urban redevelopment in the 1960s, T. Dan Smith. ${ }^{93}$ Such well-known 'conventional' planning experts were employed for their expertise and track-record, with Matthew appointed by the Ministry of Health and Local Government 'partly because of his Clyde and London experience'. ${ }^{94}$ Other considerations sometimes played a part in appointments, however, and Matthew's origins as a 'Presbyterian Scot', inadvertently for him, also conferred 'political advantages ... in winning over potential unionist opponents' ${ }^{95}$ In contrast, Nationalist senators criticized the government for going 'across the water' rather than engaging 'an Irishman' to work on the Belfast regional survey. ${ }^{96}$ What outside consultants inevitably lacked was a clear grasp of the nuanced political realities of Northern Ireland and the problematic communal 'dis-embedding' that technocratic redevelopment processes could conceivably precipitate. $^{97}$

\section{Conclusions}

A little-known aspect of the work of an important twentieth-century architect-planner has been illuminated through the discussion of Max Lock's inventory of architectural heritage in Armagh. Although modest in comparison with the interventions of Matthew in Northern Ireland, Lock's inventory influenced the subsequent actions and activities of civil society in the region, demonstrating how outside expertise and the media could be harnessed by local proponents in pursuit of their conservation-planning agenda. As such, the discussion reflected upon the diffusion of planning and state-civil society relations in Northern Ireland in the 1960s. The NT leveraged its UK-wide reach to pursue local innovations in practice, choreographing with central and local government, and effectively co-producing the inventory with public- and private-sector interests. In addition, the selection of Armagh is significant given its historic, non-industrial character and surviving core of Georgianera buildings. Conserving the character of Armagh as part of a balanced approach to modernization resonated with local policymakers and politicians who were sympathetic towards the Geddesianinspired philosophy articulated by Lock. The place promotional advantage that the local council sought to derive was not only indicative of the growing awareness of the heritage values of Armagh's built environment, but also reflected attempts at positively differentiating it from the New City project and in the context of a series of regional planning initiatives in Northern Ireland in the mid1960s.

The dashed expectations of civil society in relation to legislative advances in the mid-1960s also exposed the shifting role and purpose of the NT. The interconnected networking and constructive engagement pursued with the state proved impotent in the face of mounting political opposition to planning and local government reform. Nonetheless, the NT was reluctant to pursue a more

\footnotetext{
92"What City of the Future Could Be Like," The Armagh Gazette, 30 January 1964.

${ }^{93}$ Tewdwr-Jones, "'Oh, the Planners'," 407.

${ }^{94}$ Glendinning, Modern Architect, 327.

${ }^{95}$ Ibid.

${ }^{96}$ Ibid., 332.

${ }^{97}$ Glendinning, "'The Forgotten Revolution'," 622.
} 
combative approach, with Michael Trinick's unpublished 1962 report on coastal preservation indicating that several Northern Ireland Committee members were 'a bit frightened' of lobbying the government. $^{98}$ This is arguably unsurprising because, as elsewhere in the UK, the NT faced practical dilemmas managing the growth in membership and the expanding number of properties under its care. ${ }^{99}$ The NT also depended heavily on Northern Ireland Government for financial support and its close proximity may have somewhat tempered campaigning zeal. ${ }^{100}$ In any event, a UKwide change in emphasis was already underway from its early days as a 'national watchdog', with 'propaganda' increasingly restricted 'to the cases in which the NT was directly concerned'. ${ }^{101}$ However, this was problematic in Northern Ireland as no amenity bodies equivalent to the Society for the Protection of Ancient Buildings or the Victorian Society existed; that is, until the emergence in 1967 of the Ulster Architectural Heritage Society (UAHS) as an 'all-purpose pressure group' and more assertive voice for conservation. Significantly, several founder members of the UAHS, including its first Chairman, Charles Brett, were either members of the Northern Ireland Committee of the NT or were closely involved in some capacity in the Armagh inventory. Brett would subsequently become 'the greatest influence on historic buildings in the province', ${ }^{102}$ while the prolific recording activities of the UAHS built upon the template initially established by Lock. The transition from a collaborative towards a more combative stance in campaigning for legislative change clearly required a different type of organization, and this shifting mode of operation in civil society was also evident throughout the UK as the 1960 s progressed. ${ }^{103}$

Northern Ireland may be a 'place apart' due to its peculiar political context, but its historical experience as a devolved region for much of the twentieth century offers contemporary insights into the increasingly diffuse and fragmented governance of space within the UK. For example, recent research indicates the accelerated divergence between the four planning systems in the UK. The trend towards further regional devolution, city deals, and localism suggests that this will only increase in the future, albeit the constitutional integrity of the UK may be subject to questioning following the outcome of the EU referendum in June $2016 .{ }^{104}$ This raises a series of interrelated issues, some of which were discussed above with reference to the Armagh inventory. Firstly, with increased scope for localized policy entrepreneurship and divergence in governance arrangements between places, questions will likely arise concerning parity and the maintenance of comparative standards in public policies and practices. Secondly, the 'within-UK' diffusion of ideas and practices will gain increasing prominence as a subject of scholarly attention, thereby complementing the growing literature on international exchanges and circulating urban knowledge. Indeed, in addressing the present 'crisis' in English planning, as Ellis and Henderson argue, policymakers can learn from the development of the National Planning Framework in Scotland. ${ }^{105}$ Finally, the evolving role of civil society within these unfolding processes will also be fascinating, particularly as organizations take on ever greater responsibilities in the context of austerity and a retreating state.

\footnotetext{
${ }^{98}$ PRONI, D3839/A/1/5, Coastal Preservation in Northern Ireland.

${ }^{99}$ Nixon, "Trouble at the National Trust."

${ }^{100}$ See McClelland, "Conservation at the Crossroads."

${ }^{101}$ National Trust, Report by the Council's Advisory Committee, 21.

${ }^{102}$ Patton, "Conservation in Northern Ireland," 6.

${ }^{103}$ Hewitt and Pendlebury, "Local Associations and Participation."

${ }^{104}$ House of Commons Library, Comparison of the Planning Systems.

${ }^{105}$ Ellis and Henderson, English Planning.
} 


\section{Acknowledgements}

Thanks to the editor and the two anonymous referees for their positive comments on an earlier draft of this article.

\section{Disclosure statement}

No potential conflict of interest was reported by the author.

\section{Notes on contributor}

Andrew G. McClelland is a Postdoctoral Researcher (Marie Skłodowska-Curie Fellow) at Maynooth University, Ireland. He completed his Ph.D. at Ulster University in 2014, where his research was predominantly focused on the contested destruction of architectural heritage in Belfast in the period 1960-1989.

\section{ORCID}

Andrew G. McClelland (D) http://orcid.org/0000-0002-8894-7201

\section{Bibliography}

Abu-Dayyeh, N. "Persisting Vision: Plans for a Modern Arab Capital, Amman, 1955-2002." Planning Perspectives 19, no. 1 (2004): 79-110. doi:10.1080/0266543042000177922.

Ancient Monuments Advisory Council. A Preliminary Survey of the Ancient Monuments of Northern Ireland. Belfast: Her Majesty's Stationary Office, 1940.

Armagh County Council. Study and Proposals by Armagh County Council - A Second University for Northern Ireland. Armagh: Armagh County Council, 1964.

Bell, P.G. Planning for Armagh, 1944.

Birrell, D., and A. Murie. Policy and Government in Northern Ireland: Lessons of Devolution. Dublin: Gill and Macmillan, 1980.

Brett, C. E. B. “The Lessons of Devolution in Northern Ireland.” The Political Quarterly 41, no. 3 (1970): 261280. doi:10.1111/j.1467-923X.1970.tb01170.x.

Brett, C. E. B. Long Shadows Cast Before: Nine Lives in Ulster, 1625-1977. Edinburgh: Bartholomew, 1978.

Buchanan, R. "Foreword." In Castle, Coast and Cottage: The National Trust in Northern Ireland, authored by L. Gallagher and D. Rogers, ix-x. Belfast: The Blackstaff Press, 1992.

Bununu, Y. A., A. N. M. Ludin, and N. Hosni. "City Profile: Kaduna." Cities 49 (2015): 53-65. doi:10.1016/j. cities.2015.07.004.

Darling, E. Re-forming Britain: Narratives of Modernity before Reconstruction. Abingdon: Routledge, 2007.

Delafons, J. Politics and Preservation: A Policy History of the Built Heritage, 1882-1996. London: E. \& F.N. Spon, 1997.

Ellis, H., and K. Henderson. English Planning in Crisis: 10 Steps to a Sustainable Future. Bristol: Policy Press, 2016.

Gallagher, L., and D. Rogers. Castle, Coast and Cottage: The National Trust in Northern Ireland. 2nd ed. Belfast: Blackstaff Press, 1992.

Glendinning, M. The Conservation Movement: A History of Architectural Preservation. London: Routledge, 2013.

Glendinning, M. “The Forgotten Revolution': Northern Ireland's Heritage of Modern Reconstruction.” The Journal of Architecture 15, no. 5 (2010): 621-636. doi:10.1080/13602365.2010.519953.

Glendinning, M. Modern Architect: The Life and Times of Robert Matthew. London: Royal Institute of British Architects, 2008.

Harwood, E. "Keeping the Past in England: The History of Post-war Listing." The Journal of Architecture 15, no. 5 (2010): 671-682. 
Hendry, J. “Conservation in Northern Ireland.” Town Planning Review 48, no. 4 (1977): 373-388. doi:10.3828/ tpr.48.4.e06651345728r681.

Hewitt, L. E. "Associational Culture and the Shaping of Urban Space: Civic Societies in Britain Before 1960." Urban History 39, no. 4 (2012): 590-606. doi:10.1017/S0963926812000387.

Hewitt, L. E., and J. Pendlebury. "Local Associations and Participation in Place: Change and Continuity in the Relationship between State and Civil Society in Twentieth-century Britain." Planning Perspectives 29, no. 1 (2014): 25-44. doi:10.1080/02665433.2013.802655.

House of Commons Library. Comparison of the Planning Systems in the Four UK Countries. Commons Library Briefing Paper 07459. London: House of Commons Library, 2016.

Larkham, P. J. "The Place of Urban Conservation in the UK Reconstruction Plans of 1942-1952." Planning Perspectives 18, no. 3 (2003): 295-324. doi:10.1080/02665430307975.

Larkham, P. J., and K. D. Lilley. Planning the 'City of Tomorrow' - British Reconstruction Planning, 1939-1952: An Annotated Bibliography. Pickering: Inch's Book, 2001.

Larkham, P. J., and K. D. Lilley. "Plans, Planners and City Images: Place Promotion and Civic Boosterism in British Reconstruction Planning.” Urban History 30, no. 2 (2003): 183-205. doi:10.1017/ S0963926803001123.

Larmour, P. "Modern Movement Architecture in Ulster 1900 to 1950." In Modern Ulster Architecture, edited by D. Evans, M. Hackett, A. Hall, P. Larmour, and C. Rattray, 2-19. Belfast: Ulster Architectural Heritage Society, 2006.

Lock, M. The City of Armagh: A List of Buildings of Architectural and Historic Importance. London: Max Lock and Partners, 1964.

Lynn, C., and J. McDowell. "The Oldest City in Ireland: Armagh." In Pieces of the Past: Archaeological Excavations by the Department of the Environment for Northern Ireland 1970-1986, edited by A. Hamlin and C. Lynn, 57-61. Belfast: Her Majesty's Stationary Office, 1988.

Madgin, R. "Reconceptualising the Historic Urban Environment: Conservation and Regeneration in Castlefield, Manchester, 1960-2009.” Planning Perspectives 25, no. 1 (2010): 29-48. doi:10.1080/ 02665430903421726.

Matthew, R. H. Belfast Regional Survey and Plan 1962. Belfast: Her Majesty's Stationary Office, 1964.

McClelland, A. G. "Conservation at the Crossroads in Northern Ireland: Terence O'Neill and the Growing Concern for Architectural Heritage 1956-69.” Irish Political Studies (2016). doi:10.1080/07907184.2015. 1127915.

McClelland, A. G. "Contesting Destruction, Constructing Heritage: The Social Construction of Architectural Heritage Values in Belfast, Circa 1960-1989.” PhD diss., Ulster University, 2014.

McCullough, C., and W. H. Crawford. Armagh. Irish Historic Towns Atlas No. 18. Dublin: Royal Irish Academy, 2007.

McKinstry, R. "Introduction." In Ulster Today: A Portrait of the Architecture of the Province Past and Present as it Looks Today. Belfast: Royal Society of Ulster Architects, 1963.

Meller, H. "Gender, Citizenship and the Making of the Modern Environment." In Women and the Making of Built Space in England, 1870-1950, edited by E. Darling and L. Whitworth, 13-32. Aldershot: Ashgate, 2007.

Ministry of Health and Local Government. The Administration of Town and Country Planning in Northern Ireland. Belfast: Her Majesty's Stationary Office, 1964.

Motouchi, N., and N. Tiratsoo. "Max Lock, Middlesbrough, and a Forgotten Tradition in British Post-war Planning." Planning History 26, nos. 1-2 (2004): 17-20.

Mulholland, M. Northern Ireland at the Crossroads: Ulster Unionism in the O'Neill Years, 1960-9. Basingstoke: Macmillan, 2000.

Mulholland, M. Terence O’Neill. Dublin: University College Dublin Press, 2013.

Mulligan, K. V. South Ulster: The Counties of Armagh, Cavan and Monaghan. New Haven, CT: Yale University Press, 2013.

Murie, A. "Planning in Northern Ireland: A Survey.” Town Planning Review 44, no. 4 (1973): 337-358. doi:10. 3828/tpr.44.4.761271r7p3h65v73.

National Trust. National Trust Annual Report. Belfast: National Trust, Committee for Northern Ireland, 1959.

National Trust. National Trust Annual Report. Belfast: National Trust, Committee for Northern Ireland, 1964.

National Trust. Report by the Council's Advisory Committee on the NT's Constitution, Organization and Responsibilities. Benson Report. London: National Trust, 1968. 
New City Design Group. First Report on the Proposed New City, Co. Armagh. Belfast: Her Majesty's Stationery Office, 1964.

Newman, C. F. S. "A Short History of Planning in Northern Ireland." Journal of the Town Planning Institute 52, no. 2 (1965): 47-53.

Nixon, S. "Trouble at the National Trust: Post-war Recreation, the Benson Report and the Rebuilding of a Conservation Organization in the 1960s." Twentieth Century British History 26, no. 4 (2015): 529-550. doi:10.1093/tcbh/hwv031.

Northern Ireland Housing Trust. Annual Report of the Northern Ireland Housing Trust. Belfast: Northern Ireland Housing Trust, 1963.

O’Neill, T. The Autobiography of Terence O'Neill. London: Hart-Davis, 1972.

Patterson, P., and E. Kaufmann. Unionism and Orangeism in Northern Ireland Since 1945: The Decline of the Loyal Family. Manchester: Manchester University Press, 2007.

Patton, M. "Conservation in Northern Ireland since 1969." Association for Studies in the Conservation of Historic Buildings Transactions 23 (1998): 3-14.

Pendlebury, J., and I. Strange. "Centenary Paper: Urban Conservation and the Shaping of the English City." Town Planning Review 82, no. 4 (2011): 361-392. doi:10.3828/tpr.2011.23.

Planning Advisory Board. The Ulster Countryside: Report on Amenities in Northern Ireland. Belfast: His Majesty's Stationary Office, 1947.

Royal Society of Ulster Architects. Ulster Today: A Portrait of the Architecture of the Province Past and Present as it Looks Today. Belfast: Nicholson and Bass, 1963.

Shapely, P. People and Planning: Report of the Committee on Public Participation in Planning (The Skeffington Committee Report) with an Introduction by Peter Shapely. Abingdon: Routledge, 2014.

Smith, O. S. "Central Government and Town Centre Redevelopment in Britain, 1959-1966." The Historical Journal 58, no. 1 (2015): 217-244. doi:10.1017/S0018246X14000077.

Tewdwr-Jones, M. “'Oh, the Planners did their Best': The Planning Films of John Betjeman.” Planning Perspectives 20, no. 4 (2005): 389-411. doi:10.1080/02665430500239448.

Tewdwr-Jones, M. Urban Reflections: Narratives of Place, Planning and Change. Bristol: Policy Press, 2011.

Uduku, O. "Networking and Strategic Deal-making in the Caribbean: Using Archives to Examine Max Lock's 1950s Planning Adventures in the West Indies." ABE Journal 4 (2013). doi:10.4000/abe.783.

Ward, S. V. "Re-examining the International Diffusion of Planning." In Critical Readings in Planning Theory, edited by S. Fainstein and A. Scott, 479-498, 3rd ed. Chichester: Wiley-Blackwell, 2012.

Ward, S. V. "Soviet Communism and the British Planning Movement: Rational Learning or Utopian Imagining?” Planning Perspectives 27, no. 4 (2012): 499-524. doi:10.1080/02665433.2012.705127.

Weatherup, D. R. M. "Introduction: The City of Armagh." In The Buildings of Armagh, authored by R. McKinstry, R. Oram, R. Weatherup, and P. Wilson, xi-xiv. Belfast: Ulster Architectural Heritage Society, 1992. 